\title{
SUB-ACUTE STENT THROMBOSIS AND IN-STENT RESTENOSIS ASSOCIATED WITH ANTIPLATELETS CLOPIDOGREL RESISTANCE AND PROTEIN S DEFICIENCY
}

\author{
M Zakky Kurniawan, Iswanto Pratanu \\ Department of Cardiology and Vascular Medicine \\ Faculty of Medicine, Universitas Airlangga, \\ Dr Soetomo Hospital, Surabaya
}

\begin{abstract}
ABSTRAK
Kekurangan protein $S$ dan antiplatelets clopidogrel bertanggung jawab atas terjadinya trombosis arteri koroner. Artikel ini membahas kasus seorang pasien dengan penyakit koroner yang telah menjalani PCI, namun dua hari kemudian pasien mengalami stent thrombosis. PCI primer dilakukan kemudian dengan hasil yang baik, tapi setelah evaluasi 4 bulan dengan uji treadmill kami menemukan depresi ST signifikan di bagian terkait. Diduga pasien mengalami in-stent re-stenosis. Pemeriksaan hematologi lebih lanjut menunjukkan bahwa pasien ini memiliki resistensi antiplatelets clopidogrel dan kekurangan protein S. Diberikan antiplatelet ganda dengan antiplatelet jenis lain dan antikoagulan. Pertimbangan lainnya yang ada adalah pilihan untuk strategi reperfusi.
\end{abstract} (FMI 2015;51:214-220)

Kata kunci: trombosis stent sub-akut, PCI, in-stent re-stenosis, resistensi anti-platelet clopidogrel, kekurangan protein S

\begin{abstract}
Protein S deficiency and antiplatelets clopidogrel resistance may uncommonly be responsible for coronary artery thrombosis. Hereby we report a patient presented with coronary disease, who had undergone PCI. However, two days later the patient was found in-stent thrombosis. Primary PCI was performed later with good result, but after 4 months evaluation with treadmill test we found significant ST depression in related region. It was suspected the patient had in-stent re-stenosis incidence. Further hematologic investigation showed that this patient had antiplatelets clopidogrel resistance and protein $S$ deficiency. Double antiplatelet with another kind of antiplatelets and anticoagulant had given in this case. However, the remaining consideration is the choice for reperfusion strategy. (FMI 2015;51:214-220)
\end{abstract}

Keywords: sub-acute stent thrombosis, PCI, in-stent re-stenosis, anti-platelets clopidogrel resistance, protein S deficiency

Correspondence: M. Zakky Kurniawan, Department of Cardiology and Vascular Medicine, Faculty of Medicine, Universitas Airlangga, Dr Soetomo Hospital, J1 Prof dr Moestopo 6-8, Surabaya 60286, Indonesia. Email:

zakkykurniawan@yahoo.com

\section{INTRODUCTION}

Protein $\mathrm{S}$ is a plasma protein which serves to inhibit the blood clotting cascade. This protein deficiency causes increased risk of thrombosis. Although during this deficiency of protein $\mathrm{C}$ or protein $\mathrm{S}$ more commonly cause thrombosis in venous system, the arterial thrombosis is one issue that should be taken into account (National Institute of Health, Acar et al 2006). Arterial thrombosis caused by a deficiency of protein $\mathrm{C}$ or protein $\mathrm{S}$, although extremely rare, can cause several clinical manifestations. There are some reports on the cases of stroke, myocardial infarction, renal infarction and peripheral arterial occlusion caused by protein $\mathrm{C}$ or protein S deficiency (Cheng et al 2012).

Clopidogrel resistance is defined as the complete blockade/inhibition of the P2Y12 receptor membrane. This can occur due to variations in clopidogrel absorption, metabolism of clopidogrel or clopidogrel combined with platelet-specific receptor. The use of thienopiridine clopidogrel, prasugrel, or ticlopidine as Double Antiplatelets Agent combination with aspirin compared cyclopentyltriazolopyrimidine ticagrelor or warfarin for the prevention of the incidence of stent thrombosis in some studies show effective results in aspirin with clopidogrel/ticlopidine/prasugrel with fewer higher advantage in Aspirin-prasugrel (study TRITON -TIMI 38). Whereas, antiplatelet resistance rates as the cause of stent thrombosis still vary, either at installation using a BMS or DES (Kirtane \& Stone 2011, Buchanan et al 2012).

In patients with myocardial infarction, management strategy of patients with this disorder is not widely discussed. Reperfusion strategy and long-term management is still based on the experience of individual clinicians. This article reported a patient with subacute 
stent thrombosis after PCI procedure and in-stent restenosis due antiplatelets clopidogrel resistance and deficiencies of protein $\mathrm{S}$.

\section{CASE REPORT}

A woman, Ms. C, 58, went to Penang, Malaysia with risk factors of dyslipidemia, and coronary heart disease was found. DCA was done and significant narrowing was identified, ranging from osteal LAD up to mid LAD and proximal RCA. Then, PTCA was done with everolimus eluting stenting. After Osteal $\mathrm{Cx}$ Compromised stenting and kissing Balloon with Cx Osteal residual stenosis $>50 \%$ were done, it was followed with implantation of a stent in the RCA. The patient was then sent home the next day with Cilostazol and Ticagrelor therapy. Thereafter, the patient returned home to Surabaya the following day.

During the flight, the patient experienced chest pain. After arriving in Surabaya, the patient visited a cardiologist, and was declared as having heart attack, with the ECG showing anteroceptal STEMI. Angiography was immediately done and we found total thrombosis in newly installed stent. Primary PCI was performed immediately, ended with the kissing balloon without stent implantation again. The patient was discharged a few days later with DAPT treatment of aspirin and clopidogrel. After intra-stent thrombosis had been managed, good outcome was obtained postrevascularization, although there was still residual thrombus within the stent.

Four months later the patient underwent treadmill stress test and obtained ST depression with significant segment in lead inferior and anterolateral so it was advisable for repeated coronary angiography. Laboratory results showed $295 \%$ clopidogrel platelet reactivity; control 281\%, Aspirin $445 \%$ control $550 \%$. This suggested that the patient was resistant to clopidogrel and aspirin sensitive. The results of the examination of protein $\mathrm{S}$ with the results of $42 \%$ (controls $83 \%$ ), Protein C $112 \%$ (107\% control). In conclusion, there was protein $\mathrm{S}$ deficiency, so in addition to being resistant to clopidogrel, the patient was also deficient in protein $\mathrm{S}$.

\section{DISCUSSION}

Based on the time of occurrence, stent thrombosis can be grouped into four, acute stent thrombosis (0-24 hours after stent implantation), subacute stent thrombosis (24 hours-30 days after stent implantation), late stent thrombosis (30 days-1 year post implantation of the stent) and very late stent thrombosis (> 1 year ) (Brener et al 2013, Antolin 2004).

Based on the classification according to the Academic Research Consortium (ARC), stent thrombosis is divided into definite, probable, and possible. Declared as definite if there is thrombus confirmed using the results of angiography coming from within the installed stent or in segments as far as $5 \mathrm{~mm}$ at the proximal and distal stent, accompanied by signs of ischemic chest pain at rest or ECG-specific, as well as up and down cardiac markers within up to 48 hours post-stenting. Declared as probable when there is death of unknown cause after 30 days of stenting or the index procedure, as well as the presence of repeated infarction in areas related to the stent installation, as proved by with or imaging if no repeated angiography that can prove the occurrence of new stent thrombosis or lesions in other sites. Then, it was declared as possible when there is death of unknown cause 30 days after the procedure was carried out.

Acute Stent Thrombosis is an event of typical chest pain that occurs suddenly with a change in ECG profile presenting as acute ischemic in accordance with the distribution of the affected blood vessel arising <24 hours after stenting installation in coronary interventions. Sub-acute stent thrombosis itself is marked by sudden typical chest pain with changing ECG profile of acute ischemic in accordance with the distribution of blood vessels that have been installed with stent, with no evidence of involvement of new lesions, and the increase of cardiac marker, within a period of 24 hours to 30 days post procedure. Late and very late stenting is classified based on time of occurrence of thrombosis post-stent installation/ implantation procedure, which is characterized by angiographic results that show definitive presence of stent thrombosis. Angiographically, stent thrombosis is a complete or partial occlusion of the blood vessel segments where the stent is installed mounted, with evidence of thrombus (Wenaweser et al 2005). The risk factors have been identified which could increase the occurrence of stent thrombosis can be divided into originating from the characteristics of the patient, characteristics of lesion and procedural factors/ properties of the stent. Patient characteristics include: gene polymorphism, the use of antithrombotic inadequate, resistance of antiplatelet effect of Acetyl Salysilat Acid (ASA) and the class of thienopyridine (Buchanan et al 2012, Dangas et al 2011), patients with acute coronary syndromes and the presence of thrombus, kidney failure, low ejection fraction, smoke, decreased TIMI flow or diabetes mellitus, (Dangas et al 2011, Aoki et al 2009), resistance to antiplatelet, and interrupted use of antiplatelets (Buchanan et al 2012, Dangas et al 2011, Lipe \& Ornstein 2011). 


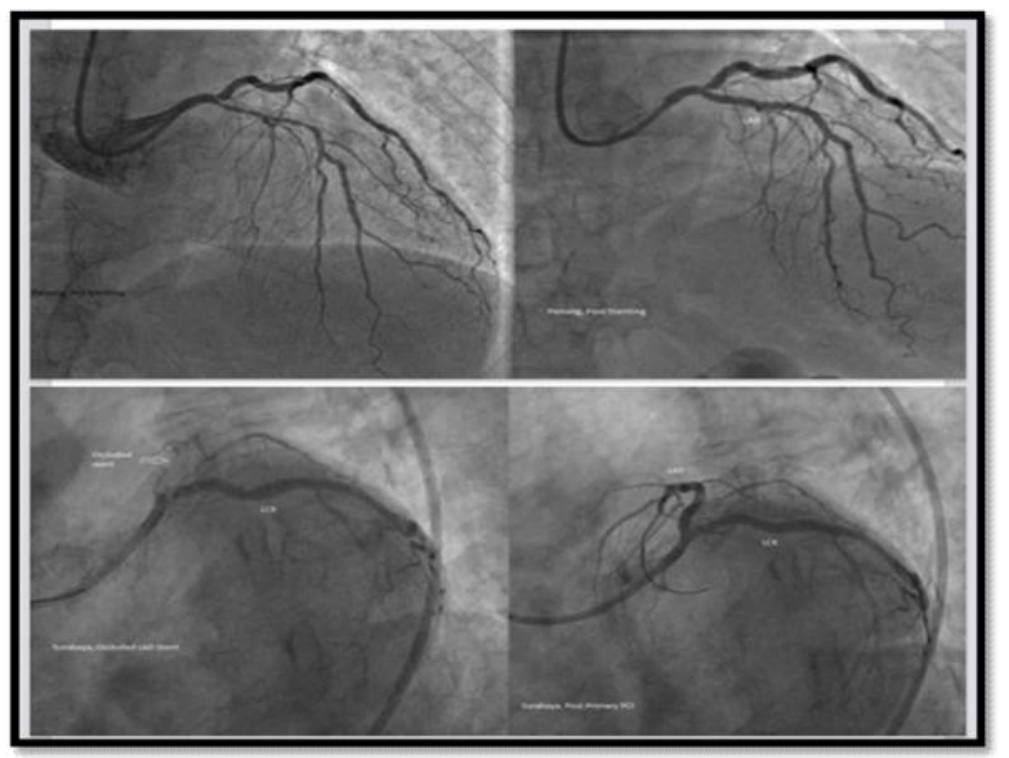

Figure 1. Result of PTCA in Penang, Malaysia, and PPCI in Surabaya

Lesion characteristics include: bifurcation lesions, lesions length, small diameter blood vessels, chronic total occlusions, diffuse disease, and thrombus containing lesions (Buchanan et al 2012, Aoki et al 2009).

Procedural factors include incomplete/less optimal stent expansion, stent malposition, a stent is placed in the target of small blood vessels or stent with small diameter, placement of multiple stents (especially the implantation of a stent in bifurcation and overlapping stents), stent placed over existing thrombus or a stent is placed over stent containing residual dissection or previous thrombus before (Buchanan et al 2012, Aoki et al 2009). The natures of the stent itself are the type of stent (BMS or DES), the polymer layer, the thickness of the framework (strut thickness), the design of the stent and the stent's length (Brener et al 2013, Elmariah \& Jang 2012, Buchanan et al 2012, Aoki et al 2009).

Antiplatelet resistance, especially the thyenopyridine group of clopidogrel types, is related to the incidence of cardiovascular events, in this case infarction or ischemia, although it has received the appropriate dose clopidogrel both during and after PTCA. This occurs because of inadequate platelet aggregation inhibition due to individual variability to clopidogrel, thus affecting the individual variability in the response of platelets with ADP. Clopidogrel is a pro-drug that requires oxidation by cytochrome $\mathrm{P} 450$ isoenzymes, followed by conversion to the active thiol metabolite by PON1 enzyme paraoxonase and PON3, before it can inhibit platelet function. Therefore, the individual variation in enzyme activity (eg, polymorphism) and/or receptor occupancy will affect in vitro effect of clopidogrel on platelet aggregation, clinical effectiveness, as well as an increased risk of bleeding. In the wide analysis of genome association, it is estimated that 83 percent of the individual variance in response to clopidogrel is due to genetic effects (Kirtane \& Stone 2011, Buchanan et al 2012).

Restenosis primarily suspected when their recurring symptoms as symptoms of acute coronary syndrome with a more stable condition. The study by Cleveland in 1186 Instent restenosis (ISR) cases with BMS as much as $9.5 \%$ appeared as IMA/STEMI $2.2 \%$ and $26.4 \%$ unstable angina. While in some other studies DES stent restenosis by nearly $27 \%-50 \%$ appeared as unstable angina symptoms, and 5-11\% appeared with symptoms of myocardial infarction. ISR definitive diagnosis is confirmed by coronary angiography, often performed as a therapeutic catheterization-based replication as initial therapy for stenting (Kirtane \& Stone 2011, Buchanan et al 2012).

Indication of intervention with re-angiography and revascularization in patients with a history of repeat stenting before was the same compared to that of 
patients with stable angina (Dangas et al 2011, Aoki et al 2009). If the indications of revascularization are met, percutaneous approach is more advisable than bypass surgery, using a type of Sirolimus or Paclitaxel stent when ISR occurs resulting from BMS stent (RIBS-I study, ISAR DESIRE). ISR can also occur as a result of DES stent, although this is rarer. Evaluation must be specified when angiography is performed. Some opinions suggest the use of IVUS as an evaluation of stent restenosis as well as the involvement of peri-stent area (Buchanan et al 2012, Dangas et al 2011, Aoki et al 2009). In RIBS-II study the use of repeated Sirolimus stents in restenosis DES stent provides good results. As the use of Paclitaxel, coated balloon delivers remarkable outcomes on restenotic stents, both BMS and DES (Dangas et al 2011, Aoki et al 2009).

Proteins $\mathrm{C}$ and $\mathrm{S}$ is a natural anticoagulant which is owned by our circulatory system (Brener et al 2013). Protein $\mathrm{C}$ is a glycoprotein which has a molecular weight of $62 \mathrm{kD}$, and is synthesized in the liver. Protein $\mathrm{C}$ is a proenzym inactive, whereas the active form of the protein $\mathrm{C}$ is referred to as Activated Protein C (APC). APC has the main function is as an anti-thrombosis and profibrinolitik. As the anti-thrombosis, APC along with protein S (PS) inactivates factors VA and VIIA. In profibrinolytic function, APC enables TAFI (Thrombin Activable Fibrinolysis Inhibitor) that the end result is the inhibition of fibrin degradation (Lipe \& Ornstein, 2011, Kottke-Marchant \& Comp 2002). Protein S is also synthesized in the liver, megakaryocytes and smooth muscle walls of blood vessels (Kottke-Marchant \& Comp 2002). Its function as a natural anticoagulant works through two mechanisms, namely APC dependent and APC independent. In APC-dependent PS acts as a cofactor of APC to degrade factors V and VIII, while in APC independent PS directly inhibits tenase and prothrombinase complex (Kottke-Marchant \& Comp 2002 ten Kate \& van der Meer 2008).

Protein $\mathrm{C}$ and $\mathrm{S}$ deficiency is one of the disorders included in the group thrombophilia disorders. Thrombophilia is defined as hereditary or derivative state that causes the patient to have increased risk of thrombosis. Some of the causes of hereditary thrombophilia is a deficiency of protein $\mathrm{C}, \mathrm{S}$ and antithrombin III, factor V leiden, hyperhomocysteinemia, prothrombin, as well as an increase in factor VIII, von Willebrand factor (vWF) and fibrinogen. While the cause of acquired thrombophilia is antiphospolipid antibody, cancer and hyperhomocysteinemia due to deficiency of folic acid, vitamin B6 and B12 (ten Kate \& van der Meer 2008, Kattel et al 2011).
Deficiency of protein $\mathrm{C}$ or $\mathrm{S}$ is a rare disorder. The incidence of protein $\mathrm{C}$ abnormalities ranges from 1: 16,000 to 1: 32000 , while the incidence of protein $\mathrm{S}$ deficiency is approximately 1: 20000. Protein C deficiency is caused by mutation on chromosome 2 , while protein $\mathrm{S}$ is caused by mutations in chromosome 3 (Kattel et al 2011).

The diagnosis of protein $\mathrm{C}$ or $\mathrm{S}$ deficiency obtained from the examination of hematology showing levels lower than the normal value, using quantitative (immunological) and qualitative (functional assay) methods (Antolin in 2004, Bhatt \& Hauser 2008). Quantitative examination uses ELISA analysis with monoclonal or polyclonal antibodies of protein $\mathrm{C}$ and $\mathrm{S}$. Qualitative examination uses PTT or aPTT value measurement of the plasma. In principle, in patients with protein $\mathrm{C}$ and $\mathrm{S}$ deficiency, or inactivation of factors Va and VIIIA will be reduced, so that the blood clotting time will be faster. Repeated/serial examination of protein $\mathrm{C}$ or $\mathrm{S}$ level is performed in patients with borderline levels. Genetic testing and examination of family members sometimes necessary, given the nature of the inherited disorder (autosomal dominant) (Kattel et al 2011).

When do we suspect that a patient has protein $\mathrm{C}$ or $\mathrm{S}$ deficiency? Examination of both these proteins is indicated in patients who experienced recurrent episodes of thrombosis that cannot be explained by other causes. Another indication is thrombosis at a young age $(<50$ years), unusual thrombosis location (liver, kidney), patients with a family history of blood clotting disorders, newborns with severe blood clotting disorder (DIC and purpura fulminant), and women with a history of recurrent miscarriage (National Institute of Health, ten Kate \& van der Meer 2008, Tiong et al 2003).

Given its quite important role as a natural anticoagulant, deficiency of one of these proteins will increase the risk of thrombosis. On the other hand, deficiency of both these proteins ( $\mathrm{C}$ and $\mathrm{S}$ ), in addition to having higher risk of thrombosis, will also manifest in the occurrence of vascular lesions (Kattel et al 2011, Hayashida et al 2003). The main manifestations of protein $\mathrm{C}$ or $\mathrm{S}$ deficiency is thromboemboli veins, especially in the form of DVT (Deep Vein Thrombosis) and pulmonary embolism. While the incidence of arterial thrombosis, although extremely rare, can also occur. Several authors have reported the incidence of ischemic stroke, myocardial infarction and renal artery occlusion as a result of protein deficiency (Acar et al 2006, Cheng et al 2012, Hayashida et al 2003). 


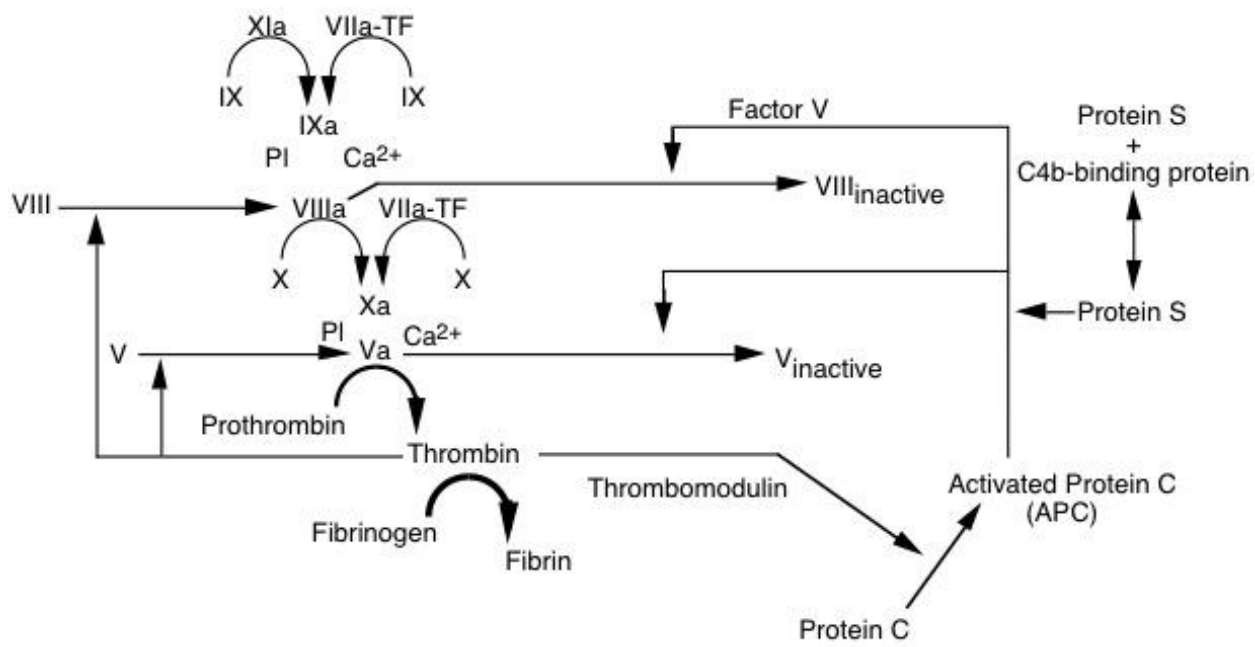

Figure 2. Role of protein $\mathrm{C}$ and $\mathrm{S}$ as natural anticoagulants

Pathophysiology of thrombus formation in arteries and veins differ slightly. The arterial system are high flow, high pressure. In conditions of deficiency of protein $\mathrm{C}$ and $\mathrm{S}$, thrombus may form spontaneously in spite of the odds. Thrombus formation is facilitated by the presence of a lesion in atherosclerosis plaque. Thrombus formed platelets containing components (white thrombus), while the venous system is low flow, low pressure. so that the thrombus may form spontaneously in this disorder. Thrombus formed is red thrombus ( $D^{\prime}$ Amato 2010).

In this case the patient had STEMI 2 days after PTCA. In addition to traditional risk factors, such as dyslipidemia, protein $\mathrm{S}$ deficiency, as well as the presence of antiplatelets resistance, other risk factors are also suspected as in this patient. However, it was s only known 4 months after the installation. Nevertheless, the diagnosis of deficiency of protein $\mathrm{C}$ and/ or protein $\mathrm{S}$ was discovered several months after undergoing a complete hematological examination to find out the cause of intra-stent restenosis based on stress test results and clinical complaints.

In the case of Acute Coronary Syndrome (ACS) associated with a deficiency of protein $\mathrm{C}$ and/or protein $\mathrm{S}$, the management principles is the same to SKA case in general. In ACS with ST elevation (STEMI), until now there has been no study comparing the most appropriate reperfusion therapy modalities in this patient group. Whether PCI or thrombolytic is more superior. Because there is no data, then we can only learn from experience in a few case reports. Damato et al say that PCI is still the main option in the case of protein C/S deficiency and SKA (D'Amato 2010). Mohatny et al say that thrombolytic therapy can also be used as an option (Mohanty et al 2004). CABG
(Coronary Artery Bypass Grafting) could be an alternative choice when PCI cannot be done. While Acar et al recommend the same, but added that if patients undergoing $\mathrm{CABG}$, a graft of arteries are preferred, particularly in the involvement of LAD (Acar et al 2006).

How does the influence of these disorders on general coronary intervention (either primary PCI or elective PCI)? Although the effect is not widely known because the incident is very rare, a hypercoagulable state that occurs in patients with protein $\mathrm{C}$ and $\mathrm{S}$ deficiency is believed to lead to increased complications in PCI action, both periprocedural and post procedural complications. Hypercoagulability and state of thrombophilia (including deficiency of protein $\mathrm{C}$ or $\mathrm{S}$ ) are associated with risk of intra-procedural thrombosis, and the occurrence of post-action restenosis. Another problem to be reckoned with is the possibility of the occurrence of stent thrombosis. Turker et al. reported the occurrence of recurrent acute stent thrombosis due to deficiency of protein C and S (Acar et al 2006).

Triple antiplatelet-anticoagulant (Aspirin, clopidogrel and warfarin) should be given during the 1st year (Acar et al 2006). However, because warfarin in case of deficiency of protein $\mathrm{C}$ and $\mathrm{S}$ can cause warfarininduced skin necrosis, several other reports recommend dabigatran (D'Amato 2010). Although the management is provided as explained above, the risk for thrombosis and late stent thrombosis remains unpredictable. As for the selection of the type of stent, there is no clear data, but in all cases, all clinicians use DES stent.

In this case, the patient was diagnosed with STEMI anteroseptal 2 days post-PCI in Penang, Malaysia and Primary PCI showed subacute stent thrombosis. 
However, four months later after the action treadmill was performed with positive results in the form of a significant depression in the inferior leads and anteroceptal. The laboratory results revealed clopidogrel resistance and protein deficiency $\mathrm{S}$.

Management of protein $\mathrm{C}$ and $\mathrm{S}$ deficiency generally depends on manifestations experienced by patients. Patients without symptoms and without clinical manifestations need not be given any treatment. Prophylactic therapy in this (asymptomatic) patient group should be considered when patients are at increased risk of thrombosis, such as prolonged immobilization and pregnancy. Whereas in patients with clinical manifestations such as thromboemboli, both venous and arterial, should receive anticoagulant therapy for 3 months to 1 year.

In patients with recurrent thrombosis, long-term anticoagulation should be considered. Provision of concentrate protein $\mathrm{C}$ is only done in cases of acquired immunodeficiency (Lipe \& Ornstein 2011, Hayashida et al 2003). Although support from studies are insufficient, a lot of literatures reveal that the basic treatment of thromboemboli due to deficiency of protein $\mathrm{C}$ and $\mathrm{S}$ is anticoagulation (Lipe \& Ornstein 2011, Kattel et al 2011, Hayashida et al 2003). While antiplatelets clopidogrel resistance can be handled by increasing clopidogrel dose of $600 \mathrm{mg}$ pre-PCI then maintenance dose $150 \mathrm{mg} /$ day, or replacement of thionepyridine type with other types that deliver meaningful outcomes, such as prasugrel, ticlopidine, or ticagrelol combined with aspirin. Aspirin should not be discontinued for 6-12 months, so as to reduce the incidence of stent thrombosis (Kattel et al 2011, Tiong et al 2003, Hayashida et al 2003).

The next question is when do we have to suspect a patient as having PCI failure given the high rarity of this disorder? Until now there has been no recommendation when we have to check the levels of protein $\mathrm{C}$ and $\mathrm{S}$, or hematologic examination on other causes of thrombophilia in a patient undergoing PCI. Selection of which patients should be examined becomes important, given the examination fee is not cheap. A study found that a complete hematologic examination is not recommended as a routine examination. Hematologic examination is only performed in patients who experienced recurrent episodes of thrombosis after other causes are removed. Tests to find the cause of thrombophilia is also recommended to be done gradually in Phase 1 and Phase 2. Phase 1 includes sensitive Creactive protein levels (hsCRP), fibrinogen, VWF Ag, factor VII, activated protein $\mathrm{C}$ resistance (clotting test), homocysteine , folic acid, B12, D-dimer, Lp (a), anticardiolipin antibodies, lupus anticoagulant. Phase 2 includes protein $\mathrm{C}$, protein $\mathrm{S}$, antithrombin III, factor $\mathrm{V}$ Leiden, and euglobulin clot lysis time (Hayashida et al 2003). With this gradual examination, we may expect to save costs in patient examination.

\section{CONCLUSION}

Further investigation of patients with sub-acute stent thrombosis after PCI procedure shows clopidogrel resistance and protein $S$ deficiency. This causes the patient fell into a hypercoagulable conditions that increased the risk of thrombosis. The management in this patient group is still an issue due to the rarity of the data. However, the choice of reperfusion strategy in the form of PCI is considered to be the best choice, although the risk of stent thrombosis is higher than that in normal population. This was followed adjunct therapy with double standard antiplatelet therapy of aspirin combined with other than clopidogrel and anticoagulants.

\section{REFERENCES}

Acar G, Dogan A, Altinbas A, Turker Y (2006). Recurrent acute stent thrombosis associated with protein $\mathrm{C}$ and $\mathrm{S}$ deficiencies. Int $\mathrm{J}$ Cardiovasc Imaging 22, 333-337

Antolin RH (2004). Complications and how to deal with them. In: Kay P, Sabate M, Costa MA (eds). Cardiac Catheterization and Percutaneous Interventions, Oxfordshire, Taylor \& Francis

Aoki J, Lansky AJ, Mehran R, Moses J, Bertrand ME, McLaurin BT, Cox DA, Lincoff AM, Ohman EM, White HD, Parise H, Leon MB, Stone GW (2009). Early stent thrombosis in patients with acute coronary syndromes treated with drug-eluting and bare metal stents: the Acute Catheterization and Urgent Intervention Triage Strategy trial. Circulation 119, 687-698

Bhatt SH and Hauser TH (2008). Very late stent thrombosis after dual antiplatelet therapy discontinuation in a patient with a history of acute stent thrombosis. Ann Pharmacother 42, 708-712

Brener SJ, Cristea E, Kirtane AJ, McEntegart MB, Xu K, Mehran R, Stone GW (2013). Intra-procedural stent thrombosis: a new risk factor for adverse outcomes in patients undergoing percutaneous coronary intervention for acute coronary syndromes. JACC Cardiovasc Interv 6, 36-43

Buchanan GL, Basavarajaiah S, Chieffo A (2012). Stent thrombosis: incidence, predictors and new technologies. Thrombosis 2012, 956962

Cheng YC, Tsai CS, Lin YC, Kao CH, Tsai YT (2012). Multiple episodes of arterial thrombosis in a young 
man with protein $\mathrm{C}$ deficiency: a case report. Vascular 20, 318-320

D'Amato R (no year). Myocardial infarction in the young. Available from http://spo.escardio.org/eslides/ view.aspx?eevtid $=48 \& f \mathrm{p}=1065$. Accessed June 13, 2014

Dangas GD, Caixeta A, Mehran R, Parise H, Lansky AJ, Cristea E, Brodie BR, Witzenbichler B, Guagliumi G, Peruga JZ, Dudek D, Möeckel M, Stone GW (2011). Frequency and predictors of stent thrombosis after percutaneous coronary intervention in acute myocardial infarction. Circulation 123, 1745-1756

Elmariah S and Jang IK (2012). Acute stent thrombosis: technical complication or inadequate antithrombotic therapy? An optical coherence tomography study. JACC Cardiovasc Interv 5, e3- e4

Genetics Home Reference (2013). Protein C deficiency. Available from https://ghr.nlm.nih.gov/condition/ protein-c-deficiency. Accessed May 20, 2014

Hayashida M, Yamada H, Yamazaki S, Nomura H, Yoshimura K, Kitahara O, Momose K, Kubo K, Kurihara M, Hamasaki N (2003). Combined protein C and protein $S$ deficiency in a family with repetitive thromboembolism and segregated gene mutations. Intern Med 42, 268-272

Kattel S, Regmi S, Neopane A, Karki DB (2011). Combined protein $\mathrm{C}$ and protein $\mathrm{S}$ deficiency presenting as deep vein thrombosis. Journal of Coagulation Disorders 3, 71-73

Kirtane AJ and Stone GW (2011). How to minimize stent thrombosis. Circulation 124, 1283-1287

Kottke-Marchant K and Comp P (2002). Laboratory issues in diagnosing abnormalities of protein $\mathrm{C}$, thrombomodulin, and endothelial cell protein $\mathrm{C}$ receptor. Arch Pathol Lab Med 126, 1337-1348

Lipe B and Ornstein DL (2011). Deficiencies of natural anticoagulants, protein $\mathrm{C}$, protein $\mathrm{S}$, and antithrombin. Circulation 124, e365-e368

Mohanty D, Ghosh K, Khare A, Kulkarni B (2004). Thrombophilia in coronary artery disease: a double jeopardy. Indian J Med Res 120, 13-23

ten Kate MK and van der Meer J (2008). Protein S deficiency: a clinical perspective. Haemophilia 14, 1222-1228

Tiong IY, Alkotob ML, Ghaffari S (2003). Protein C deficiency manifesting as an acute myocardial infarction and ischaemic stroke. Heart 89, E7

Wenaweser P, Rey C, Eberli FR, Togni M, Tüller D, Locher S, Remondino A, Seiler C, Hess OM, Meier B, Windecker S (2005). Stent thrombosis following baremetal stent implantation: success of emergency percutaneous coronary intervention and predictors of adverse outcome. European Heart Journal 26, 11801187 